\title{
A Rewriter at Work
}

\author{
Nikephoros Xanthopoulos and the Pege Miracles
}

\author{
Stavroula Constantinou
}

\section{$1 \quad$ Rewriting and the Miracle Story Collection ${ }^{1}$}

Rewriting is a common enterprise among Byzantine hagiographers who cultivate genres such as Passion, saint's Life and Enkomion. ${ }^{2}$ Being an open-ended

1 The title of my chapter alludes to Cyril Mango's famous article: "A Byzantine Hagiographer at Work: Leontius of Neapolis" (in Byzanz und der Westen: Studien zur Kunst des europäischen Mittelalters, ed. Irmgard Hutter (Sitzungsberichte der philosophisch-historischen Klasse) 432 (Vienna, 1984), pp. 24-41) to suggest that a Byzantine hagiographer is also a rewriter. In fact, this is valid for Leontios himself who in the case of the Life of Symeon the Holy Fool, as Mango argues, "expand[s] it [a paterikon] into a Vita" ("Byzantine Hagiographer at Work," p. 30).

2 The Menologion of Symeon Metaphrastes, for instance, includes these three hagiographical genres. For the rewriting of texts belonging to these genres that was performed by either Metaphrastes and his team or other Byzantine authors, see, for example, Kristoffel Demoen, "John Geometres' Iambic Life of Saint Penteleemon: Text, Genre and Metaphrastic Style," in Philomathestatos: Studies in Greek and Byzantine Texts Presented to Jacques Noret for his Sixty-fifth Birthday, ed. Bart Janssens, Bram Roosen, and Peter Van Deun (Leuven, 2004), pp. 165-84; Stephanos Efthymiadis, "John of Sardis and the Metaphrasis of the Passio of St. Nikephoros the Martyr (BHG 1334)," Rivista di Studi bizantini e neoellenici 28 (1991), 23-44; Bernard Flusin, "Vers la Métaphrase," in Rémanier, Métaphraser: Fonctions et techniques de la réécriture dans le monde byzantin, ed. Smilja Marjanović-Dušanić and Bernard Flusin (Belgrade, 2011), pp. 85-99; Laura Franco, "A Study of the Metaphrastic Process: The Case of the Unpublished Passio of St James the Persian (BHG 773), Passio of St Plato (BHG $155^{-}{ }^{-52}$ ) and Vita of St Hilarion (BHG 755) by Symeon Metaphrastes," unpublished PhD diss. (Royal Holloway University of London, 2010); Martin Hinterberger, "Die Konstantinsvita im späten Byzanz: Einer Gegenüberstellung palaiologenzeitlicher Metaphrasen," Graeco-Latina Brunensia 16 (2011), 41-59; Hinterberger, "Hagiographische Metaphrasen: Ein möglicher Weg der Annäherung an die Literarästhetik der frühen Palaiologenzeit," in Imitatio, Aemulatio, Variatio: Akten des internationalen wissenschaftlichen Symposions zur byzantinischen Sprache und Literatur (Wien, 22-25 Oktober 2008), ed. Andreas Rhoby and Elisabeth Schiffer (Vienna, 2010), 137-51; Hinterberger, "Between Simplification and Elaboration: Byzantine Metaphraseis Compared," in Textual Transmission in Byzantium: Between Textual Criticism and Quellenforschung, ed. Juan Signes Codoñer and Inmaculada Pérez Martín (Lectio: Studies in the Transmission of Texts and Ideas) 2 (Turnhout, 2014), pp. 33-6o; Christian Høgel, Symeon Metaphrastes: Rewriting and Canonization (Copenhagen, 2002); Høgel, "Symeon Metaphrastes and the Metaphrastic Movement," in The Ashgate 
text, the miracle story collection, ${ }^{3}$ on the contrary, is rarely used for rewriting purposes whereas it frequently yields literary continuations. ${ }^{4}$ As Byzantine hagiographers themselves repeatedly point out, a holy person does not cease to perform miracles through which divine power is incessantly manifested in the human world. For example, the anonymous hagiographer of the 1othcentury collection of the Theotokos of the Source or Pege miracles writes in his prologue:

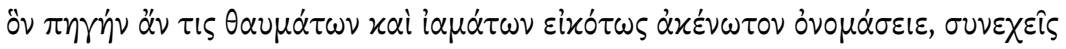

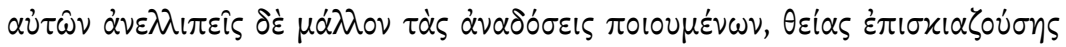

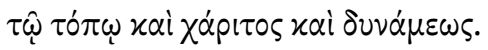

Research Companion to Byzantine Hagiography, ed. Stephanos Efthymiadis, 2 vols. (Farnham, UK, 2011-14), 2: 181-96; Lev Lukhovitskiy, 'Nikephoros Gregoras' Vita of St. Michael the Synkellos: Rewriting Techniques and Reconstruction of the Iconoclast Past in a 14th cent. Hagiographical Metaphrasis," Jahrbuch der Österreichischen Byzantinistik 64 (2014), 177-96;

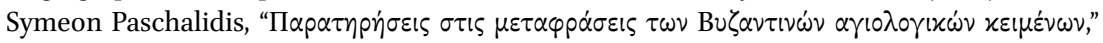

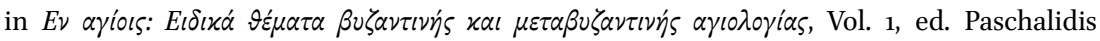
(Thessalonike, 2011), 75-88; Elisabeth Peyr, "Zur Umarbeitung rhetorischer Texte durch Symeon Metaphrastes," Jahrbuch der Österreichischen Byzantinistik 42 (1992), 143-55; Daria Resh, "Toward a Byzantine Definition of Metaphrasis," Greek, Roman and Byzantine Greek Studies 55 (2015), 754-87; Elisabeth Schiffer, "Metaphrastic Lives and Earlier Metaphraseis of Saints' Lives," in Metaphrasis: Redactions and Audiences in Middle Byzantine Hagiography, ed. Christian Høgel (Bergen, 1996), 22-42; Alice-Mary Talbot, “'Old Wine in New Bottles': The Rewriting of Saints' Lives in the Palaeologan Period," in The Twilight of Byzantium, ed. Slobodan Ćurčić and Doula Mouriki (Princeton, NJ, 1991), pp. 15-26; Henric Zilliacus, "Zur stilistischen Umarbeitungstechnik des Symeon Metaphrastes," Byzantinische Zeitschrift 38 (1938), 333-50.

3 The characteristics of the hagiographical genre of the miracle story collection are discussed in Stavroula Constantinou, Byzantine Thaumaturgic Narratives: The Art of Miracle Story Collection, forthcoming. For an introduction to the genre, see Stephanos Efthymiadis, "Collections of Miracles (Fifth-Fifteenth Centuries)," in Efthymiadis, Ashgate Research Companion, 2:103-42.

4 See, for example, the two miracle story collections of Demetrios: the work of the bishop of Thessalonike John (second half of the 7 th c.) and its anonymous continuation composed 70 years later. Another example are the miracles of Kosmas and Damian which have come down to us in six series dating from the sixth to the 14th century. It wouldn't be an exaggeration to say that the large majority of Byzantine miracle story collections are the works of more than one author. Modern scholars and editors of these texts have often detected the original anthology and the later additions. Concerning, for instance, the collections of Anastasios the Persian and Artemios (7th c.), see Bernard Flusin, Saint Anastase le Perse et l'histoire de la Palestine au début du VII ${ }^{e}$ siècle, 2 vols. (Paris, 1992), I: 111-15; John Haldon, "Supplementary Essay. The Miracles of Artemios and Contemporary Attitudes: Context and Significance," in The Miracles of St. Artemios, trans. Virgil S. Crisafulli and John W. Nesbitt (Leiden, 1997), pp. 33-73, at pp. 34-35. 
One could reasonably call it $<$ the shrine $>$ an inexhaustible source of miracles and healing cures, which issue forth continuously, or rather unceasingly, as both divine grace and power overshadow the place. ${ }^{5}$

Accordingly, throughout the time in which the genre of the miracle story collection is cultivated in Byzantium (5th-14th c.) there is a considerable number of hagiographers, who feel obliged or are commissioned to add a number of new miracles to an existing collection that is mostly associated with a particular shrine.

Within the corpus of Byzantine miracle story collections (about 18 texts), there are two important works that constitute rewritings of earlier collections while at the same time they include selections of new miracles, combining thus the literary practice of rewriting with that of continuation. These texts are: the collection of Kosmas and Damian's miracles at the Kosmidion shrine in Constantinople, which was composed by a certain Maximos the Deacon, and that of the Virgin which is related to Pege, another Constantinopolitan shrine, that is a work of the prolific author Nikephoros Xanthopoulos. ${ }^{6}$ Possibly it is no coincidence that both texts, which were written in Constantinople about the same time - the first decades of the 14th century — were produced in the so-called Palaiologan era, that is one of the par excellence periods of Byzantine hagiographical rewriting. ${ }^{7}$

5 Byzantine text in Acta Sanctorum Nov. III (1910), 878-89, at 878; trans. Alice-Mary Talbot in Talbot and Scott Fitzgerald Johnson, Miracle Tales from Byzantium (Dumbarton Oaks Medieval Library) 12 (Cambridge, MA, 2012), pp. 203-97, at p. 205.

6 Despite the importance of Xanthopoulos' work, it has not received much scholarly interest. Some relevant studies are the following: Theodora Antonopoulou, "The 'Brief Exegesis of John Climacus' Heavenly Ladder' by Nikephoros Kallistos Xanthopoulos: Remarks on its Nature and Sources," Jahrbuch der Österreichischen Byzantinistik 57 (2007), 149-68; Jeffrey M. Featherstone, "Three More Letters of Nicephorus Callistus Xanthopoulos," Byzantinische Zeitschrift 91.1 (1998), 20-31; Christian Gastgeber and Sebastiano Panteghini, eds., Ecclesiastical History and Nikephoros Kallistou Xanthopoulos (Österreichische Akademie der Wissenschaften, philosophisch-historische Klasse Denkschriften) 477 (Vienna, 2015); Martin Jugie, "Poesies rhythmiques de Nicéphoros Kallistos Xanthopoulos," Byzantion 5 (1929-30), 357-9o; Athanasios Papadopoulos-Kerameus, "Nikephoros Kallistos Xanthopoulos," Byzantinische Zeitschrift 11 (1902), 38-49.

7 See Alice-Mary Talbot, "Metaphrasis in the Early Palaiologan Period: The Miracula of Kosmas and Damian by Maximos the Deacon," in Heroes of the Orthodox Church, the New Saints, 8th-16th c., ed. Eleonora Kountoura-Galake (Institute for Byzantine Research, International Symposium) 15 (Athens, 2004), 227-37; Talbot, “'Old Wine in New Bottles"; Talbot, "Hagiography in Late Byzantium (1204-1453)," in Ashgate Research Companion, 1:173-95, at pp. 17679. For other Byzantine periods in which hagiographical rewriting flourishes, see Part 1 of this volume. 
In contrast to other hagiographical rewritings, the two miracle collections in question have not attracted much scholarly attention. ${ }^{8}$ Ludwig Deubner, the editor of the hagiographical dossier of saints Kosmas and Damian, prepared an edition of Maximos' additional miracles only. As he emphatically points out in the introduction of his edition, "die so veränderten Erzählungen haben natürlich für uns keinerlei Wert" (emphasis added). ${ }^{9}$ Deubner's decision to exclude from his edition Maximos' reworking of the saints' previous miracle stories for being "worthless" has left this Byzantine author's work with a partial and unavoidably unsatisfying edition, rendering thus difficult its appropriate study. Concerning the work of Xanthopoulos, it has had a better editorial fate, since it has been published in its entirety, yet its early 19th-century edition (1802) by Ambrosios Pamperis is nothing more than a manuscript transcription. ${ }^{10}$ However, a proper critical edition is under preparation by Alexander Alexakis and Alice-Mary Talbot.

Deubner's automatic dismissal of Maximos' rewriting project, along with the general lack of philological interest in providing an edition of his entire work reflect contemporary scholars' aesthetic ideology, which as a rule treats rewriting as a repetitive and evidently uninteresting work. ${ }^{11}$ Rewriting, in contrast, is, as theorists such as Gérard Genette and Edward Said have shown, not only the sine qua non of originality, but also the very condition of literature. ${ }^{12}$ In his essay "On Originality," Said notes:

8 For a list of studies examining rewritings of Passions, saints' Lives, and Enkomia, see n. 2 above, as well as a number of chapters in this volume. As for Maximos' collection of Kosmas and Damian's miracles, there are a couple of articles discussing it (Stephanos Efthymiadis, "Late Byzantine Collections of Miracles and Their Implications," in Heroes of the Orthodox Church, 239-5o and Talbot, "Metaphrasis in the Early Palaiologan Period"). For Xanthopoulos' rewriting of the Pege miracles, there are also a couple of articles that are devoted to the two Pege collections produced by the same scholars (Stephanos Efthymiadis, "Le monastère de la Source à Constantinople et ses deux recueils de miracles: Entre hagiographie et patriographie," Revue des Études Byzantines 64-65 (2006-07), 283-309 and Talbot, "Two Accounts of Miracles at the Pege Shrine in Constantinople," Travaux et Mémoires 14: Mélanges Gilbert Dagron (2002), 605-15).

"The narratives that have been changed in such a way [stylistically, including also highly didactic additions] have, of course, no value for us" (Ludwig Deubner, Kosmas und Damian: Texte und Einleitung (Leipzig, 1907), p. 29).

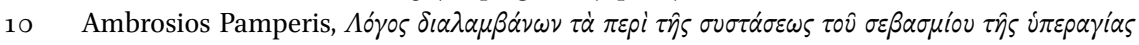

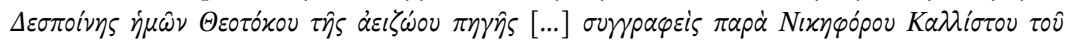

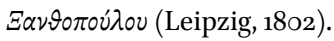

11 Similarly, Stephanos Efthymiadis comments that the most interesting part of Xanthopoulos' miracle collection is the one that constitutes a continuation of the 1othcentury text (Efthymiadis, "Le monastère de la Source à Constantinople et ses deux recueils de miracles," p. 300).

12 Genette's rewriting theory is thoroughly discussed in the volume's first chapter, and it is also used for the analysis undertaken and in Chapters 6-8 of this volume. 
The best way to consider originality is to look not for first instances of a phenomenon, but rather to see duplication, parallelism, symmetry, parody, repetition, echoes of it - the way, for example, literature has made itself into a topos of writing. [...] The writer thinks less of writing originally, and more of rewriting. [...] Much of what I have been saying about the transformation of the imaginative terms by which we can now understand originality is indicated in the French critical phrase le refus du commencement. [...] Thus the fabric of the novel, as well as its theme, is made of rewriting, one original cantus firmus being imitated so many times as to lose its primacy. ${ }^{13}$

In other words, all literary writing is, in a sense, rewriting. ${ }^{14}$ At the same time, as pointed out in Chapter 1 of this volume, rewriting constitutes an inherent characteristic of postmodern literature. As, for example, Linda Hutcheon and Fredric Jameson have argued, postmodern aesthetics are essentially citational and repetitive. ${ }^{15}$ In fact, rewriting does not only characterize postmodern literature, but it has also been an important feature of Byzantine aesthetics. ${ }^{16}$ A considerable number of Byzantine authors, both religious and profane, employ rewriting as a literary strategy to establish their authorial identities as writers. ${ }^{17}$ As rewriters, they demonstrate in the most graphical way how an original composition can be achieved by reinscribing older texts into a new context where they take on new meanings, and serve different agendas. Being a common phenomenon in Byzantine literature, rewriting should be seriously taken into consideration in order to achieve its better understanding. Thus,

\footnotetext{
13 Edward W. Said, The World, the Text and the Critic (Cambridge, MA, 1983), pp. 135-36.

14 See also the relevant discussion in Chapter 1 of this volume.

15 Linda Hutcheon, A Theory of Parody: The Teachings of Twentieth-Century Art Forms (Chicago, 1985); Hutcheon, A Poetics of Postmodernism: History, Theory, Fiction (London, 1988); Hutcheon, The Politics of Postmodernism (London, 1989); Fredric Jameson, Postmodernism, or, the Cultural Logic of Late Capitalism (Durham, NC, 199o).

16 For other parallels and affinities between Byzantine and postmodern literature and culture, as well as for the influences of the first upon the latter, see Per-Arne Bodin, "Holy Foolishness and Postmodern Culture," in Holy Foolishness in Russia: New Perspectives, ed. Priscilla Hart Hunt and Svitlana Kobets (Bloomington, IN, 2011), pp. 353-72; Helena Bodin, "Into Golden Dusk': Orthodox Icons as Objects of Late Modern and Postmodern Desire," in Wanted Byzantium: The Desire for A Lost Empire, ed. Ingela Nilsson and Paul Stephenson (Uppsala, 2014), pp. 201-16; Stavroula Constantinou, "A Byzantine Hagiographical Parody: The Life of Mary the Younger," Byzantine and Modern Greek Studies 34.2 (2010), 16o-81.

17 Such authors are Symeon Metaphrastes, Constantine Porphyrogennetos, and Nikephoros Ouranos; see Catherine Holmes, "Byzantine Political Culture and Compilation Literature in the Tenth and Eleventh Centuries: Some Preliminary Inquiries," Dumbarton Oaks Papers 64 (2010), 55-80.
} 
apart from hagiographical rewriting whose study is promoted through the present volume, rewriting in other Byzantine genres, such as historiography, hymnography, homiletics, romances, and didactic literature should also receive systematic attention. ${ }^{18}$

Provided that the rewriting project of Maximos remains inaccessible due to the lack of a complete edition of his work, the following discussion focuses on that of Xanthopoulos and its relation to the history of the Pege shrine. My analysis falls into two parts. The first, larger part deals with Xanthopoulos' originality. It will be shown how an established author of the early Palaiologan era, such as Xanthopoulos, produces a new text through rewriting the 1oth-century Pege miracle collection. In so doing, he aims at creating a more powerful and appealing work that would supersede its model. Xanthopoulos' purpose appears justified if one takes into consideration the fact that the anonymous collection, despite its freshness, vividness, and charming minimalism, does not seem to have been popular in Byzantium as it survives in a single 12thcentury manuscript. ${ }^{19}$ The survival of Xanthopoulos' collection in several manuscripts, on the other hand, is an indication that he managed to largely achieve his purpose.

After exploring Xanthopoulos' rewriting art, I hope to show in the second part of my analysis how his work functions as a tool for imperial, anti-Latin, and Orthodox propaganda. According to Alice-Mary Talbot, the collection of Xanthopoulos reflects a desire to "promote the cult of the Zoodochos Pege, and [is] primarily hagiographical in nature."20 Talbot, nevertheless, does not mention any other uses of the new collection produced by Xanthopoulos. As will be demonstrated here, Xanthopoulos' main nonliterary purposes through the rewriting and continuation of the 1oth-century miracle collection of the Source were to support and promote the imperial propaganda of Andronikos II Palaiologos (1282-1328) who worked hard to prove himself as an Orthodox and legitimate emperor. ${ }^{21}$

18 For a short discussion of rewriting in different Byzantine genres and a presentation of relevant scholarship, see the volume's introduction.

19 Stephanos Efthymiadis, "Greek Byzantine Collections of Miracles: A Chronological and Bibliographical Survey," Symbolae Osloenses 74 (1999), 195-211, at 205; Efthymiadis, "Le monastère de la Source à Constantinople et ses deux recueils de miracles," p. 288.

$20 \quad$ Alice-Mary Talbot, "Epigrams of Manuel Philes on the Theotokos tes Peges and Its Art," Dumbarton Oaks Papers 48 (1994), 135-65, at 137.

21 For Andronikos II's reign see, for example, Edmund Fryde, The Early Palaeologan Renaissance (1261-c.1360) (The Medieval Mediterranean) 27 (Leiden, 200o), pp. 91-102; Angeliki E. Laiou, Constantinople and the Latins: The Foreign Policy of Andronicus II, 1282-1328 (Cambridge, MA, 1972); Donald M. Nicol, The Last Centuries of Byzantium 12611453, 2nd ed. (Cambridge, UK, 1993), pp. 91-147; Kostis Smyrlis, "Financial Crisis and the 
In what follows, I shall refer to the two Pege miracle collections by employing the Genettean terms hypertext and hypotext that were introduced in the volume's first chapter. In our case, the hypotext is the anonymous 1oth-century collection whereas that of Xanthopoulos is the hypertext. The hypertext, which is presented as a "Logos concerning the establishment of the church of the Theotokos at the Spring," is a bipartite work with a prologue and an epilogue framing each part. The first part includes 40 independent narratives. The first 39 miracles are reworkings of those of the hypotext covering a large period of about five centuries, from the mid-5th to the mid-1oth century. Nevertheless, most of these miracles appear to have been performed between the gth and the 1oth centuries, a period which is closer to that of the author. ${ }^{22}$ The last and fortieth miracle, which allegedly takes place in the 1oth century, is absent from the hypotext and seems to be either Xanthopoulos' own addition or a story that he takes from another source that so far remains unidentified.

As for the second part of Xanthopoulos' work, it constitutes a chronological continuation of the first segment, and it includes 15 new miracles which occur mostly during the reign of the Emperor Andronikos II. The last miracle

Limits of Taxation under Andronicus II Palaiologus (1282-1321)," in Power and Subversion in Byzantium: Papers from the Forty-third Spring Symposium of Byzantine Studies, Birmingham, March 2010, ed. Dimiter Angelov and Michael Saxby (Society for the Promotion of Byzantine Studies Publications) 17 (Farnham, UK, 2013), pp. 71-82.

A common practice among Byzantine authors of miracle collections is to recount miraculous events that took place in their own times or in the previous century. Obviously, this practice was established for authenticity reasons. The anonymous hagiographer of the earliest miracle collection that has come down to us, that of Thekla (5th c.), writes

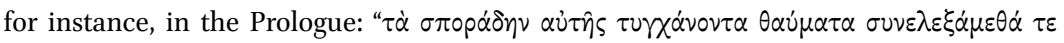

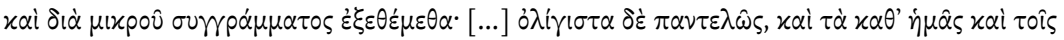

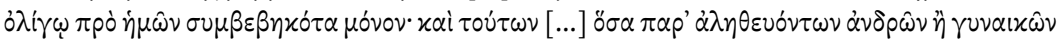

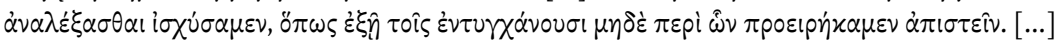

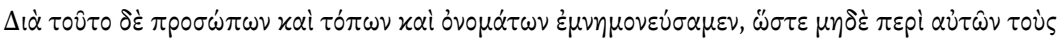

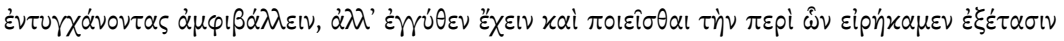
$\tau \hat{\jmath} \varsigma \alpha \lambda \eta \theta \varepsilon i \alpha \varsigma$ " (I have assembled her miracles scattered here and there and published them in this small collection. [...] This is a very small portion, and only those that happened in my time or among those who lived a short time before us. And of these [...] as many as I have been able to collect from reputable men and women, in order that the audience should not distrust the events we have previously described. [...] For this reason, I have made mention of people, places, and names, so that the audience has no doubts about these events, but rather can consider them from close up and examine the truth of what I have said" (trans. Scott Fitzgerald Johnson in Miracle Tales, p. 3; ed. in Gilbert Dagron), Vie et miracles de sainte Thècle (Subsidia Hagiographica) 62 (Brussels, 1978), p. 284). 
of the continuation is the largest and most detailed one, but not without reason. It relates the healing of Makarios, a monk from the Spring monastery suffering from a respiratory ailment and kidney stones, who, as Xanthopoulos informs us, is the person that has commissioned the composition of the new collection. ${ }^{23}$

Some of the reasons why the Virgin of the Spring's miracle collection is selected for the rewriting project undertaken by Xanthopoulos might, as Talbot has pointed out, be related to the revival of Mariolatry in the Palaiologan period, the association of the commissioner of the text with the shrine, and the wish to both attract pilgrims to a Constantinopolitan monastery, as well as to enhance faith in a difficult period for the Empire. However, next to these external factors there are also internal or textual ones which derive from the anonymous collection itself. In other words, as the following discussion will indicate, it is also the 1oth-century text that, through its programmatic statements and its general form and character, fosters its very rewriting and continuation. Being a skillful reader, writer, and rewriter, Xanthopoulos identifies the gaps, implications, and ambiguities of the hypotext, which he fills, makes explicit, brings to completion, and even exaggerates through his own unique way of rewriting. But how does the hypotext prompt Xanthopoulos to rewrite, unwrite, reencode, and continue it? And in which ways does he undertake to do so?

In the prologue of the hypotext, the author states programmatically:

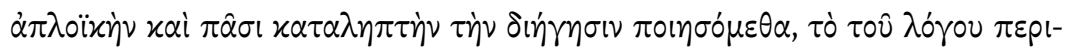

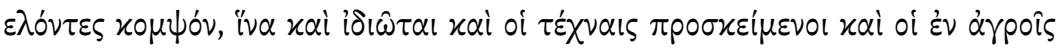

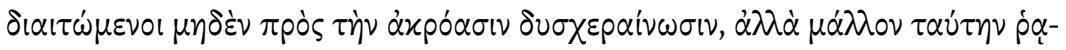

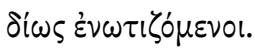

I will make the account simple and understandable to all, avoiding subtle refinement of speech, so that even ordinary people and artisans and agricultural laborers will have no difficulties listening to it, but rather will comprehend it easily. ${ }^{24}$

23 By choosing to both devote the largest miracle story of the continuation to the commissioner of the collection and have it at its very end, Xanthopoulos follows the practice of Sophronios the monk, sophist, and later bishop of Jerusalem (634-38) who in his own collection of the miracles of Kyros and John adds at the end (as the seventieth miracle) the story of his personal miraculous cure that is the largest of the whole collection.

24 Trans. Alice-Mary Talbot in: Talbot and Fitzgerald Johnson, Miracle Tales from Byzantium, pp. 203-97, at p. 207. 
With this very statement, the anonymous author defines the nature of his intended audience which does not include Byzantine intellectuals looking for sophisticated language and rhetorical pleasure. This does not remain a mere statement, as is often the case in Byzantine prologues where authors give promises that they never fulfill. ${ }^{25}$ The anonymous author puts his words into practice by using throughout his text a very simple and clear language expressed in short sentences or longer ones with an easy structure. As is the case with many hagiographical texts, the style of the hypotext often becomes biblical, since the figures of speech and the quotations employed by the author are mostly taken from the Scriptures. ${ }^{26}$

In Xanthopoulos' hands, the first author's style undergoes a complete transformation. The rewriter replaces his predecessor's words with archaic forms. He changes the original single verbs or nouns into periphrases, and adds descriptive words. In so doing, Xanthopoulos renders his own sentences long and complicated, a fact that makes their reading difficult. The complexities and particularities of Xanthopoulos' text lie also in his constant use of medical terms and rhetorical devices, such as metaphors, similes, images, comparisons, hyperboles, repetitions, and wordplay. An indicative example of Xanthopoulos' personal style is the following passage, that is the beginning of the first prologue which starts with the image of a thirsty and sunburned traveler who comes across a pleasant spring. This image, which is absent from the hypotext, is given in a long sentence that takes up six and a half printed lines:

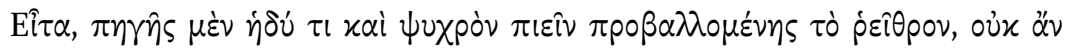

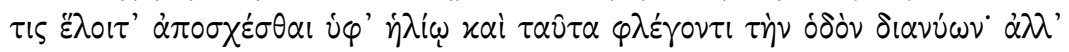

\footnotetext{
25 For the presence of proems in Middle Byzantine hagiography, see Thomas Pratch, Der hagiographische Topos (Millennium Studies) 6 (Berlin, 2005), pp. 19-55.

26 See, for example, the following quotation from the Psalms which the hagiographer in-

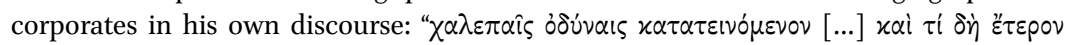

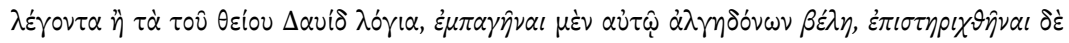

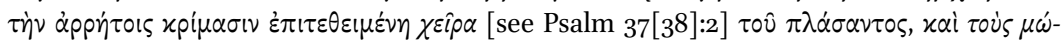

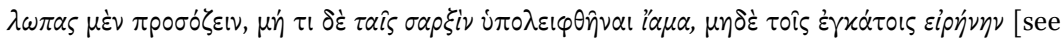

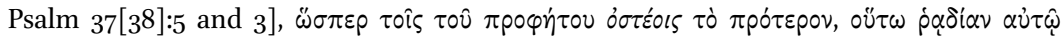

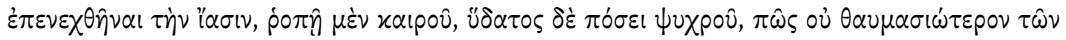
$\pi \dot{\omega} \pi 0 \tau \varepsilon$ xai $\pi \alpha \rho \alpha \delta \circ \xi \dot{\sigma} \tau \varepsilon \rho \circ \nu^{\prime}$; (Mir.11.1; "[W]racked with terrible pain [...] he may say something akin to the words of the divine David, that the arrows of pain are fixed in him, and the hand of the Creator laid upon him presses heavily through his ineffable decisions, and his bruises are noisome, and there is no healing in his flesh, nor peace in his innards, just as in the bones of the prophet of old. Thus how is it not more wondrous and miraculous than any previous miracles that he received a cure so easily, in a single moment, from a drink of cold water?", trans. Talbot, Miracle Tales, 227-28).
} 


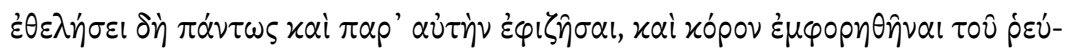

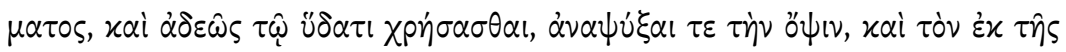

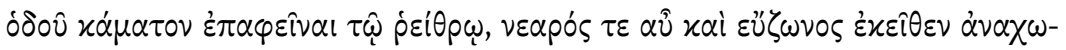
p

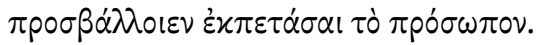

Not one person, who travels on the road and is thus burnt by the sun, would therefore choose to avoid a source pouring pleasant and cool water. He would rather sit down next to it until he drinks water to his satiety and uses it eagerly to refresh his face; and having discharged the tiredness of traveling through the water, he would leave the place fresh and agile; or possibly he would also rest upon the nice grass where he could feel the breeze across his face. ${ }^{27}$

Through the image of the tired and sweaty traveler that is revitalized by the nice and fresh water of a spring, Xanthopoulos draws a parallel with the image of the hagiographer-in this case himself-who, being thirsty for the water of life and covered by the dirt of his sins, stands before the divine and lifegiving Spring of the Virgin. In contrast to the traveler, however, the hagiographer needs the Virgin's intercession in order to be able to use the miraculous water and its innumerable cures for both his own regeneration and that of his audiences. The lyricism of the hypertext's prologue has no equivalent in the hypotext which opens as follows:

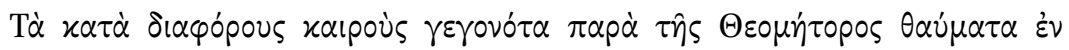

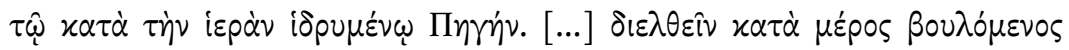

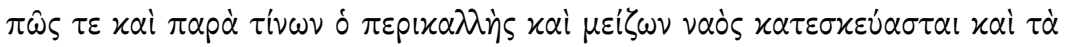

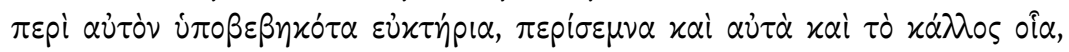
$\pi \rho \circ \sigma \omega x o \delta o ́ \mu \eta \tau \alpha$.

It has long been my desire to describe to a certain extent the miracles wrought by the Mother of God at various times in her sanctuary established at the Holy Spring [...], and how and by whom the larger and most beautiful church was constructed, as well as how the additional secondary chapels (which are also very noble and of similar beauty) were built. ${ }^{28}$

27 The translation of Xanthopoulos' text is my own.

28 Trans. Talbot, Miracle Tales, p. 205, with slight modifications of my own. 
In general, Xanthopoulos makes much fewer references to the Bible than the first author. ${ }^{29} \mathrm{He}$, on the contrary, cites, alludes to, and opens an intertextual dialogue with ancient Greek and Byzantine writers, such as Homer, the tragedians, medical authors, hagiographers (chiefly with those of miracle collections), and Prokopios. Concerning Prokopios in particular, Xanthopoulos uses his work On Buildings as a source for 6th-century Constantinopolitan buildings, the Pege Church included. ${ }^{30}$ Confronted with such a lyrical, sophisticated, and intertextual style, Xanthopoulos' reader is made to stop and reread his sentences in order to make sense of the text's densities and to enjoy its rhetoric. Needless to say, Xanthopoulos' distinctive stylistic rewriting, lyricism, and intertextuality constitute essential elements of literary creativity.

In the above citation, the 1oth-century writer declares that one of his central aims is to illustrate the ways in which the beautiful Pege building complex has been erected. Even though he describes the Pege buildings as beautiful, he does not provide details about or descriptions of their external or internal exquisiteness. Filling this gap, Xanthopoulos inserts in his text a long ekphrasis of the buildings as well as more information about their construction, renovation, and changes throughout time. He also offers detailed descriptions of the artworks that beautify the church. Additionally, he complements the building history provided in the hypotext by presenting the new additions that were made by the Virgin's beneficiaries from the 1oth century until his own time. In so doing, Xanthopoulos offers a unique literary account that covers the building history of a Byzantine monument almost in its entirety: from the $5^{\text {th }}$ century when the first building of the Pege complex was constructed until the penultimate century of the Empire.

It should be pointed out that Xanthopoulos does not restrict himself to the rhetorical descriptions of the Pege buildings, their ornaments, and mosaics. He enriches his text with further digressions, such as the ekphrasis of Constantinople and that of the Church of Saint Sophia, as well as a lamentation on the city's fall by the Crusades in 1204. The prominent place of Constantinople in Xanthopoulos' work is not an innocent or a purely aesthetic addition. On the

29 For Xanthopoulos' use of biblical citations in his major work, the Ecclesiastical History, see Felix Albrecht, "Beobachtungen zu den Bibelzitaten der Historia ecclesiastica des Nikephoros Xanthopoulos," in Ecclesiastical History and Nikephoros Kallistou Xanthopoulos: Proceedings of the International Symposium, Vienna, 15th-16th December 2011, ed. Christian Gastgeber and Sebastiano Panteghini (Veröffentlichungen zur Byzanzforschung, philosophisch-historische Klasse Denkschriften) 37 (Vienna, 2015), pp. 17-28.

30 For example, Xanthopoulos uses On Buildings for his short Enkomion and description of the Church of Saint Sophia (Prologue; On Buildings, I.i.27-78) and the Pege church that was erected by Justinian (Second Miracle; On Buildings, I.iii.6-10). 
one hand, it enhances contemporary Constantinopolitans' identity and pride in their city, and, on the other, it cultivates their resentment against the Latins who dared to destroy the Queen of Cities in 1204. It could be also seen as an implicit criticism against the anathematized Emperor Michael viII Palaiologos, Andronikos' father, for his Latin policies. Xanthopoulos' numerous references to Constantinople, which are woven into his reworking of the hypotext's first narratives, should be seen as part of his anti-Latin project which, as I will show, reaches its climax in the second part of his collection, the continuation.

In his rewriting of the miracle stories of the hypotext, apart from rhetorical additions and digressions, Xanthopoulos also makes a number of changes through which the narrative sequence and structure are altered. In healing miracles, for instance, which are central in both texts (hypotext and hypertext), ${ }^{31}$ Xanthopoulos expands considerably the description and symptomatology of the beneficiaries' illnesses. ${ }^{32}$ As has been suggested, the hagiographers' strong interest in medicine is a late Byzantine phenomenon. ${ }^{33}$ If this is the case, Xanthopoulos appears to produce a new work that takes part in the literary tendencies of his times, and thus to take into consideration the expectations and tastes of contemporary audiences.

Behaving like a specialist writing a medical manual, Xanthopoulos does not only offer explanations about the origins and symptoms of diseases, but he also elucidates how the miraculous water of the spring leads to a cure that is both easy and quick. In other words, Xanthopoulos treats the spring water and the mud it creates as a kind of medication that has therapeutic effects on a suffering body. As for the symptoms that mostly attract Xanthopoulos' interest, these are inhuman suffering and pain that are often associated with a grotesque appearance of the patient's body who is likened to a monster. ${ }^{34}$ Xanthopoulos is in fact obsessed with the violence performed on the human body by disease, as he both exaggerates his predecessor's reference to the ill pilgrims' pains and embarks in grotesque descriptions of their deformed bodies. The bodily

31 The predominance of healing miracles is a general characteristic of the Byzantine miracle collections. There are only a couple of exceptions which do not follow this rule: the two miracle collections of Demetrios. While the first collection, that of Bishop John, includes some healing miracles, the anonymous collection has no healing miracles. It consists almost exclusively of military miracles.

32 Talbot, "Two Accounts of Miracles at the Pege Shrine in Constantinople," pp. 611-15.

33 Jan Olof Rosenqvist, "Miracles and Medical Learning: The Case of St Eugenios of Trebizond," Byzantinoslavica 56.2 (1995), 461-69.

34 For the grotesque bodies of sufferers in Byzantine miracle collections, see Stavroula Constantinou, "Grotesque Bodies in Hagiographical Tales: The Monstrous and the Uncanny in Byzantine Collections of Miracle Stories," Dumbarton Oaks Papers 64 (2010), $43-54$. 
grotesque, for which there are hints in the anonymous collection, acquires its full development in Xanthopoulos' work where it becomes dominant, both in the rewriting and in the continuation. In the latter, the bodily grotesque reaches its apogee. Xanthopoulos' stark use of the aesthetic category of the grotesque constitutes an indication of the intertextual relationships between his work and the miracle collections of the early Byzantine period in which the grotesque is prominent. ${ }^{35}$

Xanthopoulos' literary treatment of illness becomes even more evident through an examination of the way in which he reworks the healing miracles of the hypotext. A case in point is the second miracle which introduces the types of diseases that are mostly cured by the miraculous water: urination problems which are caused by bladder or kidney infection. After presenting the protagonist of the narrative, that is the Emperor Justinian, the anonymous hagiographer gives the following information about his ailment: "he fell victim

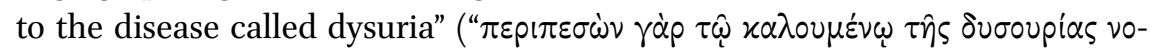
$\left.\sigma \eta^{\prime} \mu \alpha \tau \iota^{\prime \prime}\right){ }^{36}$ Then the hagiographer mentions briefly the emperor's unbearable pains and the doctors' inability to offer him a cure. All in all, the anonymous hagiographer's discussion of the disease and its symptoms takes up fewer than three printed lines.

Xanthopoulos' version, on the contrary, is much more amplified taking up 17 printed lines. He does not just name the disease, but he provides an explanation about its appearance. According to him, Justinian's retention of urine was the result of the formation of a bladder stone which was created by his hard way of life and restrained diet. Xanthopoulos also clarifies how this bladder stone blocked the emperor's urine, and how this in turn caused him immense pain. Except for its medical interest, Xanthopoulos' detailed, yet repulsive, description functions as an indirect eulogy for Justinian who is portrayed as a moderate and industrious emperor, suggesting that it is due to this very characteristic that he is eventually granted a miraculous healing through the Virgin's intercession. Xanthopoulos' encomiastic attitude toward Justinian, which is much stronger than that of his predecessor, is also manifested through the presentation of the emperor's building program that has been mentioned above.

As far as Justinian's disease is concerned, the anonymous hagiographer's single and short reference to the emperor's intolerable pains becomes a recurrent theme in Xanthopoulos' version where it governs the whole discussion about the patient's dysouria. Xanthopoulos repeatedly makes the reader focus on the emperor's sufferings, either by talking in various ways about his pains and

35 Constantinou, "Grotesque Bodies in Hagiographical Tales."

36 Trans. Talbot, Miracle Tales, p. 213. 
their escalations or by referring implicitly to them through the arresting references to the bladder stone's effects on Justinian's body. Xanthopoulos writes that as soon as the emperor drinks the spring water, the bladder stone is either expelled from his body by the water's forceful passage or it is crushed and dissolved by the water. In any case, the disappearance of the bladder stone delivers the emperor from his pains. By giving all this information, Xanthopoulos provides a better understanding of Justinian's cure and thus supplements his predecessor's version where we read just the following sentence: "As soon as he drank the water, the painful disease was cured, since the organs which produce

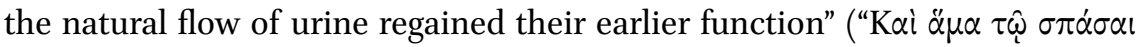

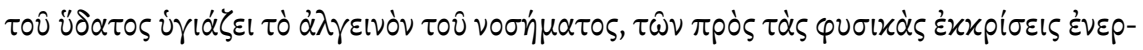

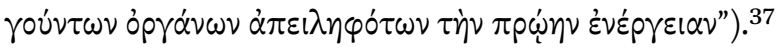

Other gaps found in the hypotext, which are filled by Xanthopoulos, concern the miracle beneficiaries and their health problems. Despite the anonymous author's declarations in both the prologue and epilogue of the collection that the pilgrims of the spring come from different places and social backgrounds and suffer from various diseases, they appear to have more or less the same origin and social status, and to become victims of similar illnesses. In his epilogue in particular, our first author writes:

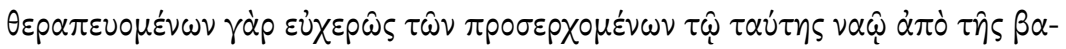

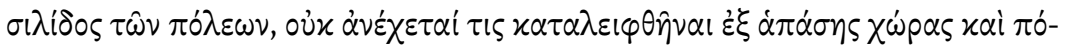

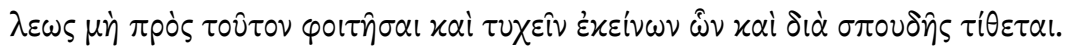

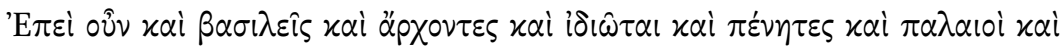

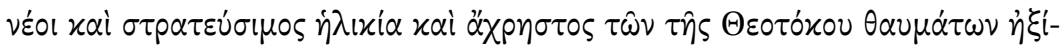

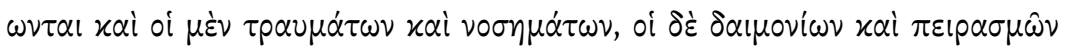

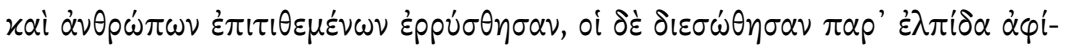

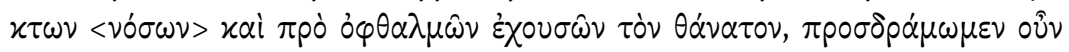

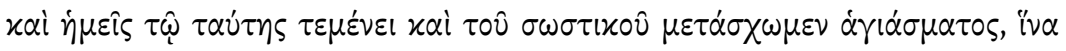

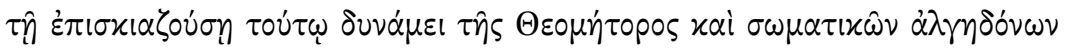

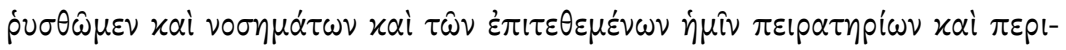
$\sigma \tau \dot{\alpha} \sigma \varepsilon \omega \nu \lambda \nu \tau \rho \omega \theta \varepsilon \dot{\eta} \mu \varepsilon \nu$.

For although those who come to her church from the Queen of Cities are readily healed, there is no one from any land and city who is unable to come to it and attain those miracles which he fervently desires. Since then emperors and officials and private persons and poor people, and the old and the young and those of military age and those unfit for military 
service were deemed worthy of the miracles of the Theotokos, some being delivered by demons and tribulations and assailants, and others being saved unexpectedly from intractable illnesses which threatened imminent death, let us hasten to her sanctuary and partake of the holy water which brings deliverance. Thus we may be saved from physical suffering through the power of the Mother of God that overshadows the holy water, and we may be delivered from illnesses and the tribulations and crises that assail us. ${ }^{38}$

The anonymous author's final words that are cited here may be read as a form of apology for the strong emphasis of the hypotext on an imperial and aristocratic clientele from Constantinople, on the one hand, and on certain health problems, such as urinary and intestinal disorders, on the other. With these very words, the author aims at dissolving any wrong impressions that his protagonists and their specific ailments might have created. He thus clarifies that the Virgin does not discriminate. Her miracles are addressed to all faithful individuals that turn to her independently of their origin, social and financial status, and health or other problems.

Xanthopoulos appears once again to read behind the anonymous author's words and to identify his intentions which he carries to completion in the best way possible. This time, the first hagiographer's statement, through which textual closure is deferred, not only provides Xanthopoulos with an easy pretext for undertaking the continuation of the collection, but it also determines the nature of the added miracles. It is no wonder that Xanthopoulos' new miracles have protagonists from various backgrounds suffering from different diseases. The 14th-century sufferers thus belong to all social classes: high (members of the imperial family, the aristocracy, and high ecclesiastical ranks), middle (merchants and bodyguards), lower (priests and anonymous poor men and women), and even the margins of society (prostitutes). They also come from a number of places: Constantinople, Sparta, Serres, Nicaea, and an island in the Black Sea. As far as their sufferings are concerned, these are different diseases, such as leprosy, carbuncles and rashes, cancer, dropsy, kidney stones, and asthma.

In sum, through his rewriting project, Xanthopoulos creates a new-and in Said's terms original - text whose literary workings take different forms. First, the Logos adopts the literary trends of the Palaiologan period (elevated style, rhetorical excess, infusion of hagiographical with medical discourse, and intertextuality involving canonical works of the ancient and Byzantine past) to fulfill the expectations of a contemporary audience for which the 1oth-century 
collection, like a number of other hagiographical texts, had exhausted its possibilities.

Second, the Logos in an imaginative way follows generic conventions of the miracle story collection which has flourished in the early Byzantine period. These include: the insistence on authenticity, the prominence of healing narratives, the centrality of the author's or commissioner's healing story, and the extensive use of the grotesque. The fact that some of these conventions (e.g. the emphasis on the commissioner's story and the grotesque) are not adopted by the anonymous hagiographer who, in turn, embraces others (e.g. simple style and biblical language) is another indication of the originality of Xanthopoulos.

Third, Xanthopoulos reworks the narratives of the hypotext in such a way that they often acquire a different meaning, form, structure, and character. For example, the narrative that has Emperor Justinian as its protagonist is quite different in the hypotext where it is comparably short, since the version of Xanthopoulos is about three times longer. In the hypotext, the narrative in question aims at recording Justinian's miraculous cure that leads the emperor to construct a church devoted to the Virgin around which the Pege building complex develops throughout time. The emphasis is on Justinian's divine dreams and the way he achieves a cure rather than on the nature of the disease and its symptoms. The hypertext, in contrast, focuses on the ailment, the suffering of the patient and his fleshliness, inviting the reader or listener to engage with the emperor's pain. Having the work of Prokopios as its source, the Logos, unlike the hypotext, includes a highly rhetorical ekphrasis of the church. The rhetorical excessiveness of the ekphrasis is as arresting as the meticulous description of Justinian's excessive fleshliness.

Fourth, the Logos, in contrast to the hypotext, is a eulogy for both the healing powers of the Virgin of the Spring and the city of Constantinople where it is situated. Finally, the Logos fills the gaps of, supplements, and continues the hypotext which invites its own reworking and continuation. In short, the Logos is, on the one hand, a sophisticated reading, rewriting, and continuation of the 1oth-century collection. On the other hand, it is a literary product of its own times, as it fits perfectly in the literary system of the first decades of the 14th century.

\section{The Logos as Imperial Propaganda}

In Xanthopoulos' case, rewriting is not only a literary exercise, but also a means of imperial propaganda. The ideological dimension of the hypertext, as is the case with its literary form and character, is induced by the hypotext. The promotion of imperial along with religious interests exists also in the 1oth-century 
collection. As has been already mentioned, the anonymous author is highly interested in imperial and aristocratic miracles which, of course, manifest the piety of certain Byzantine emperors and their courtiers who become recipients of the miraculous and undertake in return the shrine's building and decorative projects. According to the anonymous author, it is to an Emperor, Leo I (457-74) that the shrine owes its existence. The first miracle of his/her collection shows how under the Virgin's guidance and before becoming an emperor, Leo finds the muddy waters of a blocked spring with which he is instructed to anoint the blind eyes of a man who miraculously recovers his sight. When Leo becomes emperor, as the Virgin predicts during this incident, he builds the shrine's first construction.

The first author's emphasis on the shrine's imperial associations from its very beginnings is further exaggerated by Xanthopoulos in both his reworking and continuation of the Pege collection. Xanthopoulos' version of the first miracle is so amplified - as it entails a larger eulogy of the Emperor Leo and a detailed ekphrasis of his construction over the spring - that it becomes three times longer than his model's account. Yet Xanthopoulos has his own reasons for over-stressing the Emperor Leo's role in the activation of Pege as a miraculous spring.

In the introductory part of his continuation, Xanthopoulos explains how with the conquest of Constantinople by the Latins in 1204 the Pege becomes inactive after seven centuries of miraculous presence. The "divine grace and power" that used to "overshadow the place," as the anonymous hagiographer remarks in the citation from his Prologue given above, are suspended due to the Latins' barbarity and ungodliness. Xanthopoulos goes on to say that the Spring remains ineffective even after the reconquest of Constantinople by the Byzantines in 1261 because of Emperor Michael viri's impious support of the Council of Lyons of 1274, which brings about the submission of the Byzantine patriarchate to the pope.

The Spring, however, regains its miraculous powers in the 14th century. The emperor who associates his name with this miraculous reactivation is Michael's son, Andronikos II. Xanthopoulos presents Andronikos as the aforementioned Leo, the first Byzantine emperor that is involved with the shrine in the $5^{\text {th }}$ century. Andronikos emerges from Xanthopoulos' eulogy not only as a second Leo, but also as a true Byzantine emperor just like all the previous rulers who were granted the Virgin's miracles because of their exemplarity and faith, as illustrated in the previous part of Xanthopoulos' collection. Michael, in contrast, like the Empire's Latin rulers, was not a legitimate emperor, a fact that was marked by the absence of divine power from Constantinople. Interestingly, the aforementioned miracle collection of Maximos the Deacon refers also to the disappearance of miracles from 13 th-century Constantinople. 
In a rather lengthy account, Xanthopoulos underlines Emperor Michael's impiety and bad rulership which he contrasts to his son's piety and exemplarity. Through Michael's psogos (blame), Xanthopoulos establishes Andronikos' eulogy. His aim is to present the son as the exact opposite of the father, on the one hand, and to prove the son's rejection of his father, on the other. Xanthopoulos insists that it is because of the son's reversal of the father's ecclesiastical policy and the subsequent restoration of Orthodoxy that the miraculous powers of the Spring are restored. In other words, the imperial city is revisited by the divine, an act that should be seen as God's approval of the new emperor.

Xanthopoulos' praise of Andronikos continues in the context of his added miracles. In a narrative where a crowd of pilgrims is saved from an earthquake, Xanthopoulos associates Andronikos' reign with the performance of innumerable miracles. Furthermore, among the shrine's eminent beneficiaries Xanthopoulos includes Michael IX, son of the emperor, his daughter-in-law Eudocia, and two of his axe-bearing Varangian bodyguards.

Xanthopoulos' pains to establish Andronikos' imperial legitimacy is in accordance with the emperor's own attempts to justify his rulership which was questioned both because of his father's policies and because he was held responsible for the empire's decline to "the status of a second-rate power." 39 Even though Andronikos did everything he could to acquire the desired acceptance, he was not always successful. His restoration of Orthodoxy, for instance, and his complete dissociation from his father did not dissolve all suspicions against him. Therefore, since Andronikos' public acts were not always enough to secure his throne he had to use other means to achieve his purpose, and propagandistic literature could be one of them.

Of course, we cannot say whether the true commissioner of Xanthopoulos' Pege collection was the Emperor Andronikos himself. What we can say, however, is that two Palaiologan rewritings of miracle collections were to a large extent produced to assist Andronikos' efforts to establish himself as a true emperor, as was the case with his predecessors except for his father.

\section{Conclusion}

By using the example of the miracle story collection, this chapter has attempted to show how rewriting and literary continuation can offer fruitful ground for both ideological manipulation and literary experimentation. By appearing to serve his predecessor's intentions, either by rewriting or by continuing his

Nicol, Last Centuries of Byzantium, p. 93. 
collection, Xanthopoulos is nicely serving his own double purpose. First, to support the imperial and religious propaganda of Andronikos II, and, second, to provide his Palaiologan audience with a text that satisfies its expectations by being a complete miracle collection at all levels: the stylistic, thematic, informative, scientific, and narrative. As such it is intended to replace the previous collection which, as has been demonstrated, asks in one way or another for its own rewriting and continuation, if not its substitution. Of course, Xanthopoulos' two aims are inextricably related. In order for his imperial and religious ideologies to prove influential they have to be expressed in an authoritative and powerful text that is the result of his sophisticated rewriting. ${ }^{40}$

40 Theresearch for this chapterhas beenfinanced by agrantfrom the A.G.LeventisFoundation in the framework of a two-year project on Byzantine miracle story collections. I would also like to thank Christian Høgel and the anonymous readers for their valuable comments, as well as Stephanos Efthymiadis for providing me with bibliographical sources that were not available to me. 